Article

\title{
Home Gardenscapes as Sustainable Landscape Management on St. Eustatius, Dutch Caribbean
}

\author{
Briana N. Berkowitz and Kimberly E. Medley * \\ Department of Geography, Miami University, Oxford, OH 45056, USA; berkowbn@miamioh.edu \\ * Correspondence: medleyke@miamioh.edu; Tel.: +1-513-529-5010
}

Received: 29 June 2017; Accepted: 26 July 2017; Published: 27 July 2017

\begin{abstract}
Home gardens are an important topic for landscape research due to their intersectional contributions to plant diversity conservation and local livelihoods. As sites of ecological restoration, gardens transform small-scale landscapes toward higher plant richness and density. We examine "gardenscapes" on St. Eustatius, a small Caribbean island, focusing on how plants growing around a home contribute to ecological and ethnobotanical measures of plant diversity, and how residents value the importance of gardens to their livelihoods. Through a survey of 14 gardenscapes and 11 home interviews, we report 277 plant species, including 31\% native and $69 \%$ non-native, high plant densities and structural evenness, 260 plants with uses, and a total of 363 uses, especially as ornamental plants (184) and for other environmental services (16), but also food (101), health remedies (50), material uses (10) and symbolic services (2). Participants indicated that home gardening could be difficult due to drought and pests, but provided resources and incomes to livelihoods, especially through the production of food products. Several respondents reported that gardening was a declining activity on St. Eustatius, but this study shows how gardening activities offer a biocultural approach to conservation that supports plant diversity and livelihoods across the island's highly-modified natural landscape.
\end{abstract}

Keywords: Caribbean; ethnobotany; gardens; plant diversity; restoration; sustainable landscape management

\section{Introduction}

The many ways that plant diversity patterns across landscapes are culturally modified, together with ecological effects over time, reflect societal priorities and values [1]. The challenge is to effectively integrate the "ecological" importance of diversity, such as its contributions to ecosystem resilience, recovery and services, with the "cultural" importance of diversity for sustainable livelihoods [2-4]. The ways that different communities and cultures use plants show how people value biodiversity in the landscapes where they live, not only for material needs critical to their sustenance and well-being, but also for its mere existence [5,6]. Wilson's [7] (p. 22) "biophilia" references something bigger: "humanity is exalted not because we are so far above other living creatures, but because knowing them well elevates the very concept of life". "Biogeographical landscapes" can be seen as a patchwork of land areas at different stages of recovery and different levels of diversity due to natural processes and human relationships with natural resources [1]. Subtle and direct effects on the environment are changing people's relationship with the land, substantiating the need to not only support plant diversity but also biocultural knowledge about that diversity at very local levels [8-10].

Most societies were established and flourished through the process of exploiting the resources found in "wild" landscapes [11]. However, just as humans can transform natural landscapes toward lower diversity settlements or agricultural landscapes, so too can human restorative practices contribute to landscape patterns that have more diverse ecological and cultural values $[6,12]$ 
(e.g., Kimber [13] on Martinique). Ecological restoration aims to restore and repair natural functions and structures to designated lands, with the goal of returning a sense of "naturalness" to an area [14]. Higgs [15] (p. 284) elaborates on a design process that should have "a deep appreciation of what an ecosystem requires to flourish, and then making such systems possible". Restoration as a conservation land management strategy benefits from human-cultural practices that support many forms of life and ecological processes, are flexible to ecological and societal needs, and are locally adaptable to new ideas and change [16,17]. France [14] emphasizes the necessity of acknowledging and championing the role of humans in restoration, as a process and outcome.

We examine home gardens as a small-scale setting in which to explore restorative landscape management and gain views on the ecological and cultural values of plant diversity: what plants occur, why they are there, and how local land practices affect diversity patterns [18]. Gardens by design create a new landscape that can be particularly important, ecologically and culturally, in human settlements $[19,20]$. Pollan [21] proposes what he calls a "garden ethic" that accepts human interaction with nature, reflects on what fits and makes sense ecologically and culturally in local landscapes, and stays positive about the impact humans can have on a newly-defined nature. Gardening highlights "human" attributes that hold importance for restoration such as skillful practices, connections to places and natural processes, and community participation [22]. Gardens provide a "biocultural" approach to conservation that reprioritizes where local ecologies are managed and whose knowledge counts $[10,12]$. Gardening also encourages a "learning-by-doing" process that suggests potential contributions to sustainable landscape management [23] (p. 1205). For example, landscapes can be enriched through the use of native plants and planting rare species with the aim of creating a more structurally complex ecosystem [16,24]. Many gardens feature both natives and often showier non-natives, and it can take experimentation to find the right balance of aesthetics and function in a garden space. [17].

We introduce "gardenscape" to describe a portmanteau of garden and landscape that goes beyond the traditional idea of a garden as a cultivated area of plants around a home to include the presence of plants, actively managed or not, in a cultural landscape bounded by human interests. The richness and spatial structure of all plants in a defined gardenscape contribute to measures of ecological and ethnobotanical diversity. As a human created "integrated landscape" for the conservation of plant diversity, gardenscapes provide a lens through which to examine how society and biodiversity interact to promote processes of ethno-ecological change [25]. All gardens restore plant diversity, from a collection of potted plants on a balcony to expansively manicured land areas (e.g., Rapoport [26] in Argentina; Loram et al. [27] in UK; Jaganmohan et al. [28] in Bangalore, India; Gbèdomon et al. [29] in Benin). Restoration activities and values in the home area may be effectively integrated to create gardenscapes that are ecologically diverse and provide important social and economic contributions to sustainable landscape management [30,31].

Our research focuses on how home gardenscapes can contribute as sites for sustainable landscape management on the island of St. Eustatius in the Dutch Caribbean. St. Eustatius has a long history of human transformation, and ongoing developments and population growth limit the land resources that can be protected. The setting supports a strong need for local people's active involvement in ecologically restorative processes within and near their homes [32]. Following a mixed-method approach, the study asked two questions. (1) How do the plants growing around homes contribute to ecological and cultural measures of plant diversity? (2) How do people on St. Eustatius situate and value the importance of gardens to their homes and livelihoods? We worked collaboratively with home residents to complete a floristic-ecological inventory of the composition and structure of plant species, recorded cultural measures of diversity that included the number of plants with ethnobotanical uses, how plants are used and the total number of uses, and considered local perceptions on how plants are managed around their home, the opportunities and constraints for effective management and the importance of the "garden" space in their lives. St. Eustatius is a small island of limited resources, where sustainable gardening practices could improve people's livelihoods, diversify their 
diets, provide valuable services, and support biocultural knowledge and individual decisions that contribute to local plant diversity $[2,10,14,33]$.

\section{Materials and Methods}

\subsection{Study Area}

St. Eustatius provides an interesting geographical setting to look at gardens as a restorative process and outcome. Recognized as a biodiversity hot spot, the Caribbean islands form a distinct sub region within Neotropical flora, showing high species richness ( $>11,000$ plant species), high species endemism (72\%, 182 endemic genera), and distinct patterns of "island" fragmentation [34]. Each island shows a unique composition of species and habitats influenced by their physical-environmental site conditions and history of human influences [35]. The Caribbean islands especially show a deep and profound history of political-economic influences that significantly impacted the people and land over time [36]. A brief chronology highlights human migration to the islands around 4000 years ago from the South American mainland with consequent landscape change for settlement and agricultural production, a "Columbian Exchange" of people, plants, and animals between the Old and New Worlds after 1492, and a plantation legacy where large lands went into commercial production supported by African slaves [37-39]. As agriculture declined and urbanization increased towards the end of the 20th century, vegetation showed recovery [40], but these changes occurred mostly in response to changing land values and not through a conscientious decision for conservation [41].

A Caribbean legacy of gardening emerged in colonial times, both among European colonizers who brought their tradition of private and public botanical gardens, and African slaves who did their own gardening and small scale farming in order to supplement their diets, preserve their culture, and make extra money through selling produce at markets [39,42]. Previous gardening studies in the Caribbean identify gardens as places where human ecological management creates high levels of plant diversity, helps preserve indigenous knowledge and culture, and provides direct benefits to gardeners such as food, medicine, and income [43-45]. We include them among the "integrated landscape management" initiatives that locally support multi-functional contributions to agricultural production, environmental services, and livelihoods assessed by Estrada-Carmona et al. [25] in Latin America.

St. Eustatius, at $21 \mathrm{~km}^{2}$, is among the smaller Caribbean islands located in the northern Lesser Antilles (Figure 1), and, along with Saba and Bonaire, occurs in the Dutch Caribbean. These islands retain status as a Special Municipality of the Netherlands, ultimately under Dutch control but with their own local government. Topographically, the island is dominated in the southeast by the dormant Quill volcano, which reaches $601 \mathrm{~m}$ at its highest point, and in the northwest by hills that have elevations up to $294 \mathrm{~m}$, with a flat plain between known as De Kultuurvlakte where the population centers are located [32] (Figure 1). Rainfall averages around $986 \mathrm{~mm}$ per year and is seasonal, with highest rainfall during the warmer months [46]. Climate conditions across the island vary from a wetter tropical monsoon to the southeast within the hurricane zone, and a drier tropical savanna climate to the northwest. The average temperature ranges from $30^{\circ} \mathrm{C}$ in warmer months (May to November) to $24^{\circ} \mathrm{C}$ in cooler months (December to April) [46].

St. Eustatius is classified by the World Wildlife Fund as part of the Lesser Antilles Dry Forest ecoregion, which is endangered due to its small area of only $130 \mathrm{~km}^{2}$ split among five islands, a relatively high level of endemism, and a deep legacy of degradation and disturbance [47]. The vegetation on St. Eustatius is generally adapted to seasonally dry conditions and drought. De Freitas et al. [48] map 16 vegetation types, with greatest variation around Quill hill. The majority of the island, however, is classified as urban and disturbed land areas. Rojer [32] found 482 plant species on St. Eustatius, of which 85 are only found in the West Indies, 18 are only found in the Lesser Antilles, and five are limited to only a few islands, but van Andel et al. [46] cites a later unpublished survey that raises the number of vascular plant species on the island to 617. 


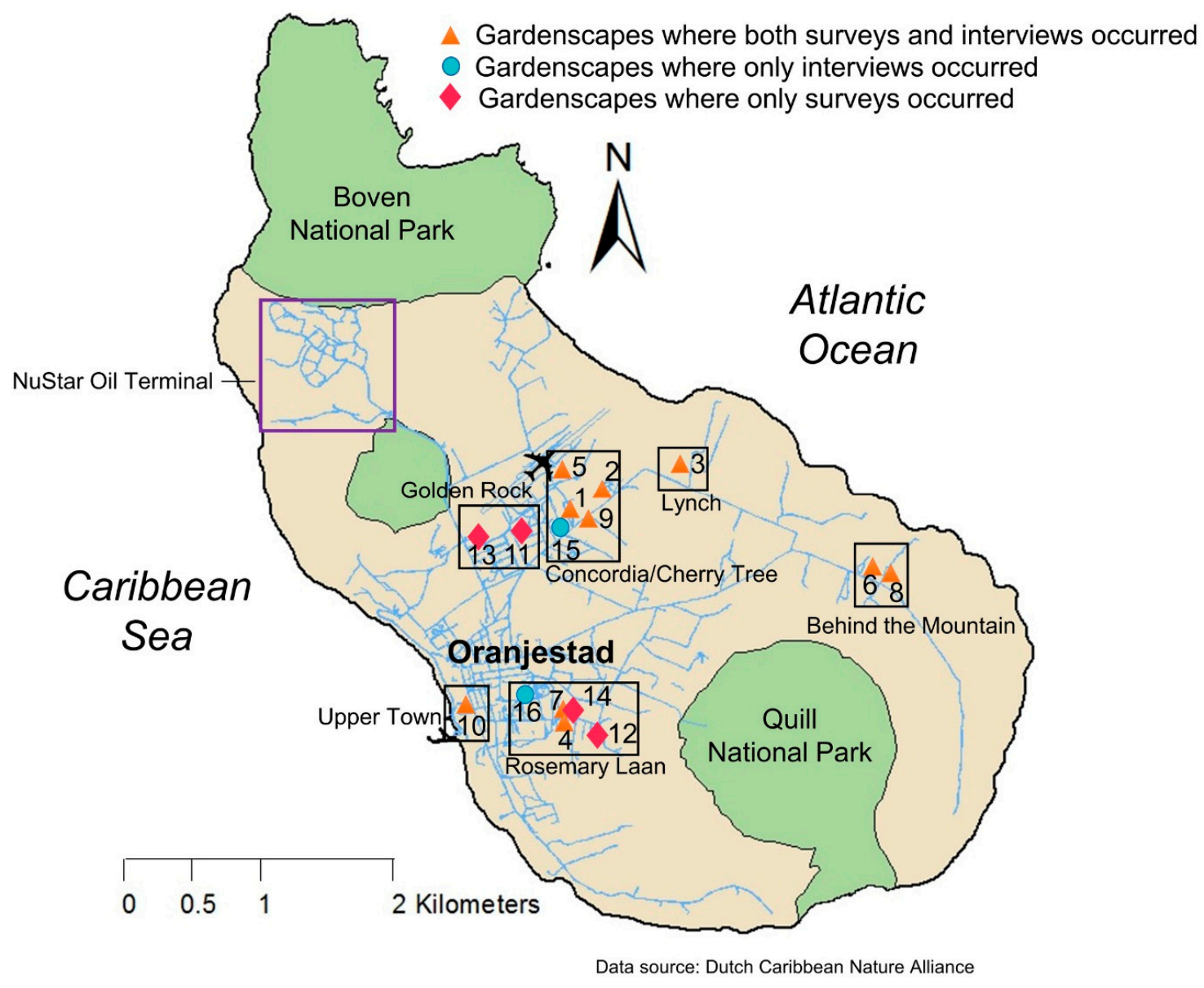

Figure 1. Gardenscape locations on St. Eustatius.

In the past, St. Eustatius would have been significantly forested, evidenced by the importance of wood derived items like canoes and wooden tools to the pre-European Saladoid people [49]. The island was spotted by Christopher Columbus during his second visit to the New World in 1493 [50] and plantations were established by the French in the 1600s, including indigo, coffee, tobacco, cotton and sugar [51]. As the number of plantations increased, so did the import of slaves from Africa, with as many as 25,000 people living on the island during the heyday of the plantation period. Plantations expanded up the slopes of Quill and the northern hills by 1650, and by 1740 all arable land was under production [52]. However, the semi-arid climate of St. Eustatius limited production on the island, and with other compounding problems such as soil erosion, nutrient loss and invasive species [48], the island turned to trade as its major industry [50]. By the mid 1700s, St. Eustatius became the commerce center of the Caribbean due to its absence of an import tax. Given the nickname of "the Golden Rock", the island gained recognition for supplying American revolutionists with weapons and ammunitions [50]. By 1840, there were just ten plantations left, and following the abolition of slavery in the Dutch Caribbean in 1863, slaves largely left the countryside to settle in towns [52]. St. Eustatius' economy dwindled in the following century, and by 1948 the population was down to only 921 people [32]. The past three decades brought new economic developments and employment through the installation of an oil terminal in 1982 and increased tourism developments. The current population is about 3200 people [53].

While most evidence of natural vegetation was destroyed under the plantation system, vegetation regeneration has since occurred in many areas. National parks were established in 1999 and are managed by the St. Eustatius National Parks Foundation (STENAPA), protecting 28\% of the island's area that include Quill hill and most of the area around Boven and Gilboa hills in the north (Figure 1). 
The secondary woodland that is growing on the island today includes many introduced and naturalized species, typical of secondary vegetation growth in the Caribbean [41].

\subsection{Selection of Gardens and Participants}

The study gained quantitative and qualitative measures of ecological and cultural diversity and local perspectives on that diversity in home gardenscapes [54]. Informed by methods in feminist and participatory research, field surveys and interviews encouraged collaborative and shared learning about home gardenscapes $[55,56]$. The research received approval for exemption by Miami University's Institutional Review Board (project 02133e) in adherence to the principles for the ethical conduct of research as described in the Belmont Report and Declaration of Helsinki. Each participant was asked to sign an informed consent form that described their participation in the study and ensured that their names would not be reported.

Berkowitz [57] led the fieldwork from June to mid-July 2016. She worked with two local field assistants who identified gardeners and gardens they knew at different locations on the island defined by their neighborhood (Figure 1). We expanded the sample by following a "snowball technique" [54] (e.g., [45]), asking the first participants to provide the names of other gardeners who they thought might participate. Each home was typically visited twice, once to introduce the project, survey the garden plants and uses with the participant and conduct an interview, and a second time to compile ethno-ecological measures and ask any follow-up questions.

We interviewed 11 home gardeners and surveyed 14 gardenscapes ( $2.14 \mathrm{ha})$ in seven named neighborhoods (Figure 1; Table 1). For two of the gardeners interviewed, we were not able to survey their garden, and in four of the gardenscapes surveyed, we were not able to interview the gardener. Sampled gardenscapes were managed by 8 females, 5 males, and two couples who shared garden labor. All participants were adults and most were in their 50s or 60s. Eight gardenscapes were managed by native St. Eustatians, and the others were from the United States (1), UK (1), Guyana (1), The Netherlands (1), and other Caribbean islands (4) (Table 1). The gardeners from elsewhere have lived on St. Eustatius for time periods ranging from five years to over three decades, and reported gardening at their current gardenscapes from one year to "many decades" (Table 1).

Table 1. Characteristics of the sampled gardenscapes.

\begin{tabular}{|c|c|c|c|c|}
\hline $\begin{array}{l}\text { Gardenscape } \\
\text { (GS) }\end{array}$ & Size $\left(\mathrm{m}^{2}\right)$ & Participants & Country of Origin & $\begin{array}{l}\text { Length of Time at } \\
\text { Gardenscape (Years) }\end{array}$ \\
\hline \multicolumn{5}{|c|}{ Gardenscapes where surveys and interviews occurred } \\
\hline 1 & 704 & Female & Aruba & 21 \\
\hline 2 & 1132 & Female & St. Eustatius & 24 \\
\hline 3 & $1750^{1}$ & Male & St. Eustatius & "many decades" \\
\hline 4,5 & $1116,492^{2}$ & Female & Dominica & "many years" \\
\hline 6 & $1817^{1}$ & Female & United States & 7 \\
\hline 7 & 6518 & Male & St. Eustatius & $\sim 15$ \\
\hline 8 & 2243 & Male & St. Eustatius & 1 \\
\hline 9 & 1077 & Female & St. Lucia & 10 \\
\hline 10 & $685^{3}$ & Male & Guyana & $2-3$ \\
\hline \multicolumn{5}{|c|}{ Gardenscapes where only surveys occurred } \\
\hline 11 & 804 & Female & St. Eustatius & 25 \\
\hline 12 & 906 & Female & St. Eustatius & not known \\
\hline 13 & 500 & Couple & St. Kitts & not known \\
\hline 14 & 1694 & Couple & St. Eustatius, UK & $3-4$ \\
\hline \multicolumn{5}{|c|}{ Gardenscapes where only interviews occurred } \\
\hline 15 & Not surveyed & Female & The Netherlands & 5 \\
\hline 16 & Not surveyed & Male & St. Eustatius & $2-3$ \\
\hline
\end{tabular}

${ }^{1}$ Gardener's property contained more area than the surveyed gardenscape. ${ }^{2}$ Gardenscape is located in a community garden managed by the Agriculture Department. ${ }^{3}$ Gardenscape is not on the gardener's property. 
Most of the sampled gardens were in the Golden Rock and Concordia/Cherry Tree neighborhoods in a densely settled area on a flat upland ( 5 interviews, 6 gardens surveyed; Figure 1). Four garden surveys and three interviews were conducted in Rosemary Laan, along a major road south of the capital Oranjestad, which runs from the top of the cliffs along a windy slope near the bay to the base of Quill hill. This setting is moister with natural vegetation, and gardenscapes are generally larger. The Upper Town gardenscape is near the edge of the cliffs by the bay at the capital Oranjestad. Two gardenscapes at Behind the Mountain are exposed to northeastern trade winds and the soil contains volcanic ash. Salt spray from the sea influences the plants on these properties. Finally, the sampled gardenscape at Lynch is located in a semi-residential area on a flat upland.

The first task was to survey with the home participants the boundary around their gardenscape. Most gardenscapes were defined by the property lines around their homes, with four exceptions. One participant rented a garden plot, one maintained a plot in a community garden, and two properties were very large so the survey only measured the land area that they identified as being more directly under their management (Table 1). Gardenscape sizes were determined first by taking GPS points in the property corners, and then taking additional points to outline the house (if present) so that it could be subtracted from the calculated area. These field measures were cross-checked with measurements of each gardenscape made on satellite imagery in Google Earth Pro. Gardenscapes ranged from 492 to $6518 \mathrm{~m}^{2}$ in size $\left(\right.$ mean $\left.=1531 \mathrm{~m}^{2}\right)($ Table 1$)$.

\subsection{Ecological and Ethnobotanical Plant Diversity}

Once the boundary of the garden was delineated, we compiled a floristic and ethnobotanical survey in collaboration with the field assistants and garden participant(s). All plants in the gardenscape were identified by genus and species and their growth habit (e.g., trees, shrubs, annual or perennial herbs). Photos and 88 voucher specimens were collected to confirm identifications, working in collaboration with Miami University's Turrell Herbarium (MU). Identification, nomenclature, and plant origins followed Plants of the Eastern Caribbean, an online database that is maintained by the University of the West Indies in Barbados, Acevedo-Rodriguiz and Strong's [58] "Catalogue of seed plants of the West Indies", Rojer's [32] floristic inventory of St. Eustatius, and a report by van der Burg [59] on naturalized and invasive plants in the Dutch Caribbean.

We also recorded the abundances of woody plants and herbaceous perennials as a measure of ecological structure. From these data, diversity attributes included floristic measures of species richness, species densities (\# species $/ \mathrm{m}^{2}$ ), total plant densities (\#/ha), relative abundances, and a comparison of composition and structural differences among the gardenscapes. PC-ORD software, which provides multivariate analyses of ecological community data, was used to calculate evenness based on relative species abundances and a jackknife estimate of species richness based on plot occurrences [60].

For the ethnobotanical survey, we recorded local plant names and uses during the field survey and in the home interviews. The study compiled the number of plant species with uses, the total number of uses, and the number of plants and uses by categories that included environmental services, food, health remedies, material uses, and symbolic services [2,61]. Ethnobotanical plant uses were compared for native and non-native plants in the gardenscapes.

\subsection{Gaining Local Perceptions on Gardenscapes}

We gained insight on how people on St. Eustatius situate and value the importance of gardens to their homes and livelihoods through semi-structured interviews, during which open-ended questions relied on participant responses to guide the interview and narratives compiled (Table 2). Of particular interest was how they transformed the garden space, engaged in gardening practices that support plant diversity, and recognized contributions from their gardenscape to their home and livelihood. Ten interviews occurred at homes and/or an identified garden space, and one interview took place at the Caribbean Netherlands Science Institute. Each interview lasted about one hour, depending on how they elaborated on their responses in relation to their gardening activities. The two research assistants 
knew most of the participants, and often joined in with asking questions or discussing certain topics with the gardeners. At several gardens, we used audio recording for the interviews, which can be particularly useful because of the anecdotal nature of ethnobotanical research (e.g., [29,62], but mostly we relied on recorded notes of their responses.

Table 2. Questions asked in the semi-structured interviews.

\begin{tabular}{l}
\hline Transformation of The Garden Space \\
\hline Where did you gain your plant and gardening knowledge? \\
What work did you do to create your gardenscape? \\
Does anyone else help you garden, and if so who? \\
How much time do you spend gardening? \\
\hline Supporting Plant Diversity in Gardenscapes \\
\hline Where did you acquire your plants (grew naturally, bought, given, etc.)? \\
What do you do to create positive change in your gardenscape? \\
What problems do you have managing your gardenscape? \\
Gardenscape Contributions to Homes and Livelihoods \\
\hline How does your gardenscape and its plants contribute to your livelihood? \\
What importance does your gardenscape and its plants have in your life? \\
How has gardening on St. Eustatius changed over the years? \\
What opportunities do you currently see for gardening on St. Eustatius? \\
\hline
\end{tabular}

\section{Results}

\subsection{Ecological and Cultural Diversity of the Gardenscapes}

Cumulatively for the gardens, the study reports 277 species in 211 genera and 75 families in a surveyed area of 2.14 ha (Table S1). The island was experiencing a drought before and during the field survey, with only $45 \mathrm{~mm}$ of rain in May and $37 \mathrm{~mm}$ in June 2016 compared to averages of $119 \mathrm{~mm}$ and $54 \mathrm{~mm}$, respectively [63]. Several participants suggested that the dry conditions may have contributed to a lower diversity or abundance of plants in their garden. Of the 277 species, 87 were trees, 67 were shrubs and 123 were herbs; 85 or 31\% are native to St. Eustatius, while 192 plants or $69 \%$ are considered non-native (Table 3). Most (162) of the non-native plants were "introduced", 25 are "naturalized", and five are "invasive" on St. Eustatius [59]. For example, the study recorded native Hymenocallis caribea in eight gardenscapes, the introduced non-native ornamental Bougainvillea sp. planted in five gardenscapes, naturalized non-native Catharanthus roseus from Madagascar occurring in seven gardenscapes, and the invasive non-native vine Antigonon leptopus in seven gardenscapes. Van de Burg et al. [59] includes a list of 80 non-native plant species in the Dutch Caribbean that may be of concern due to their potential to be invasive, but their threat on St. Eustatius is not yet known. Twenty-one of these species were reported as introduced in the gardenscapes.

Table 3. Plant species by origin status, following van der Burg [59].

\begin{tabular}{lc}
\hline \multicolumn{1}{c}{ Origin Status } & Number of Species (\%) \\
\hline Native-plants indigenous to an area. & $85(31 \%)$ \\
Introduced (exotic) - plants transported across geographical barriers by humans. & $162(58 \%)$ \\
$\begin{array}{l}\text { Naturalized - non-native plants that sustain their populations. } \\
\text { Invasive-non-native plants that spread away from their site of introduction } \\
\text { and outcompete native vegetation. }\end{array}$ & $25(9 \%)$ \\
\hline
\end{tabular}

The ethnobotanical survey recorded 260 plant species with uses and a total of 363 plant uses (Table 4 and Table S1). The study participants emphasized the aesthetic contributions of their gardenscapes and accordingly most plants (184) were introduced for their "environmental service" as 
an ornamental plant. The category with the highest number of plant uses was environmental services (187 species, 200 uses), which in addition to ornamental plants included plants selected for drought resistance or providing a supportive function to other plants in the garden (Table 4). Many of the non-ornamental plant uses, particularly those for health remedies, came from a native St. Eustatian woman and a woman originally from Dominica who had lived on St. Eustatius for many decades. Interestingly, the most common ailments treated by plants were high blood pressure and diabetes, which correlate to a new prevalence of those diseases on the island [43]. Among the plants with uses, we found 185 plants with only one use and 24 plants with three or more uses. Of the 184 plants considered ornamental, 47 (26\%) had additional ethnobotanical uses, such as Ricinus communis (castor oil plant), which is also used by women to "clean out" after having a baby, to help a baby be birthed quicker, and to condition hair.

Table 4. Ethnobotanical plant uses reported by garden participants.

\begin{tabular}{|c|c|c|c|}
\hline $\begin{array}{c}\text { Use } \\
\text { Categories }\end{array}$ & Recorded Uses (\# of Species) & $\begin{array}{c}\text { No. of } \\
\text { Uses }\end{array}$ & $\begin{array}{l}\text { No. of } \\
\text { Species }\end{array}$ \\
\hline Food & $\begin{array}{l}\text { Side dish (1), edible leaves (6), edible stalks (4), edible bulbs (2), edible fruits (47), } \\
\text { edible nuts (1), fruit used to make jam (2), fruit used to make juice (7), edible herb (9), } \\
\text { adds fiber to diet (1), milk for tea and porridge (1), used to make oil (1), good source } \\
\text { of starch (1), seeds used to flavor cooking (1), cut up and eat like string beans (1), } \\
\text { makes a cooling drink (2), used for salad (2), edible roots (4), grind seeds to make } \\
\text { coffee (1), good for flavoring soups, meat and salads (1), used to make a Christmas } \\
\text { drink (1), ferment fruit to make wine (1), edible flowers (1), leaves good for tea (2), } \\
\text { source of sugar (1) }\end{array}$ & 101 & 94 \\
\hline Material uses & $\begin{array}{l}\text { Used to cover charcoal pits (1), attracts fish so they are easier to catch (1), bowls and } \\
\text { cups can be made from the fruit (1), good for making fences (1), powder from seeds } \\
\text { used for skin decoration (1), repels mosquitos (1), used on hair (1), fish poison (1), } \\
\text { animal fodder (1), can be used as a roof on structures for shade (1). }\end{array}$ & 10 & 9 \\
\hline $\begin{array}{c}\text { Symbolic } \\
\text { services }\end{array}$ & Branches tied to fences/doors on independence day (1), cut for decorative flowers (1) & 2 & 2 \\
\hline $\begin{array}{l}\text { Health } \\
\text { remedies }\end{array}$ & $\begin{array}{l}\text { Tea to get rid of worms (1), (tea) for weight loss (2), (tea) for blood pressure (4), (tea) } \\
\text { for diabetes (6), drink juice to treat diabetes (1), pieces of plant can be eaten to treat } \\
\text { diabetes (1), jelly good for kidney and bladder (1), drink oil for colon (1), tie on foot } \\
\text { if a nail or kasha plant is stepped on to prevent tetanus and draw out poison (1), } \\
\text { good for eyes (1), tie on stomach to reduce pain (1), tea to cause an abortion (1), tea } \\
\text { to stop bleeding (1), treatment for mosquito bites (1), used to "clean out" after } \\
\text { having a baby (1), used to help a baby come out quicker during birth (1), (tea) for } \\
\text { cough (2), (tea) for dengue (1), make powder from root for prostate problems (1), } \\
\text { leaves draw down swelling (1), good for menstrual pain (2), tea to relieve pain (1), } \\
\text { helps with memory (1), treats colds (1), rub leaves on wasp stings (1), chew a piece } \\
\text { to go to sleep (1), makes a tincture for pain (1), general health remedy (1), apply to } \\
\text { face to treat mumps (1), (tea) to stop diarrhea (1), chew roots to stop pain (1), make } \\
\text { bush tea (1), drink juice to get rid of typhoid (1), leaves used to make tea (tea) to treat } \\
\text { fever (4), used to make a treatment for prostate problems (1), treatment for sores (1) }\end{array}$ & 50 & 33 \\
\hline $\begin{array}{c}\text { Environmental } \\
\text { services }\end{array}$ & $\begin{array}{l}\text { Ornamental plant (184), drought resistant (3), good for shade (2), leaves can be put } \\
\text { around plants to keep in moisture (1), hummingbirds like flowers (1), popular tree } \\
\text { habitat for iguanas (1), used as a windbreak (2), can break off a stick and plant to } \\
\text { quickly grow a tree (1), branches used to protect growing vegetables from livestock } \\
\text { (1), boil leaves to make a tea that can be applied to plant leaves to get rid of/prevent } \\
\text { pests (1), flowers attract bees (1), can grow on an arbor and have a greenhouse space } \\
\text { underneath (1), fragrant flowers (1). }\end{array}$ & 200 & 187 \\
\hline Totals & & 363 & 260 \\
\hline
\end{tabular}

Several plants were mentioned as having uses by multiple participants, such as Senna occidentalis, whose seeds can be used to make coffee, Amaranthus dubius, a green originating from West Africa that is commonly known as callaloo and used in Caribbean cooking, and Moringa oleifera, which one participant called the most important medicinal plant on St. Eustatius, and was said to help with weight loss. We reported nine uses for Cocos nucifera and five uses for Aloe vera (Table S1) that were mentioned by multiple participants.

Species richness among the gardens ranged from 22 to 92 species (mean $=55$, Table 5; Figures 2 and 3). Species density $\left(\# / \mathrm{m}^{2}\right)$ was highest in the smallest gardenscape and lowest in the largest gardenscape (see Table 1 for GS 13 and 7), but richness and species density also varied 
among gardens of similar size (Table 5). Plant densities (\#/ha) in the gardenscapes were high, with a mean of $2179 / \mathrm{ha}$, and relative abundances of species were relatively equitable with all evenness values above 0.700 .

Table 5. Ecological attributes of the gardenscapes.

\begin{tabular}{|c|c|c|c|c|c|}
\hline Island Location & Gardenscape (GS) & No. of Species & Species Density $\left(\# / \mathrm{m}^{2}\right)$ & Density (\#/ha) & Evenness \\
\hline \multirow{2}{*}{ Behind the Mountain } & 6 & 92 & 0.05 & 3089 & 0.793 \\
\hline & 8 & 22 & 0.01 & 1937 & 0.640 \\
\hline Cherry Tree & 9 & 67 & 0.06 & 2374 & 0.869 \\
\hline \multirow{4}{*}{ Concordia } & 1 & 50 & 0.07 & 2455 & 0.843 \\
\hline & 2 & 82 & 0.07 & 3367 & 0.702 \\
\hline & 5 & 37 & 0.08 & 2726 & 0.763 \\
\hline & 11 & 53 & 0.07 & 1774 & 0.778 \\
\hline Golden Rock & 13 & 57 & 0.11 & 3953 & 0.856 \\
\hline Lynch & 3 & 54 & 0.03 & 1689 & 0.803 \\
\hline \multirow{4}{*}{ Rosemary Laan } & 4 & 90 & 0.08 & 3193 & 0.872 \\
\hline & 7 & 38 & 0.01 & 640 & 0.757 \\
\hline & 12 & 54 & 0.06 & 1910 & 0.875 \\
\hline & 14 & 39 & 0.02 & 599 & 0.749 \\
\hline Upper Town & 10 & 30 & 0.04 & 794 & 0.796 \\
\hline Average & & 55 & 0.05 & 2179 & 0.793 \\
\hline
\end{tabular}

Gardenscapes with the most and lowest number of species are in the same neighborhood (Behind the Mountain) and those gardens with highest species richness occur in more arid (e.g., Behind the Mountain) and moist (e.g., Rosemary Laan) settings (Figure 1, Table 5). Species richness differences among the gardens relate more to the gardener and the purpose of the garden. For example, the three gardenscapes $(6,2$, and 4$)$ with the highest number of species were managed by older women who had more time to garden and extensive knowledge of plants and plant uses. GS 2 was less manicured, allowing for a greater number of native species (32; Figure 2). The gardener from GS 4, among the highest in richness $(90)$, species density $\left(0.08 / \mathrm{m}^{2}\right)$, density $(3193 / \mathrm{ha})$ and evenness $(0.872)$, grew many fruit trees that were used to make products both for her own use and to sell, and had collected and managed plants in her gardenscape for "many years" (Figure 4).

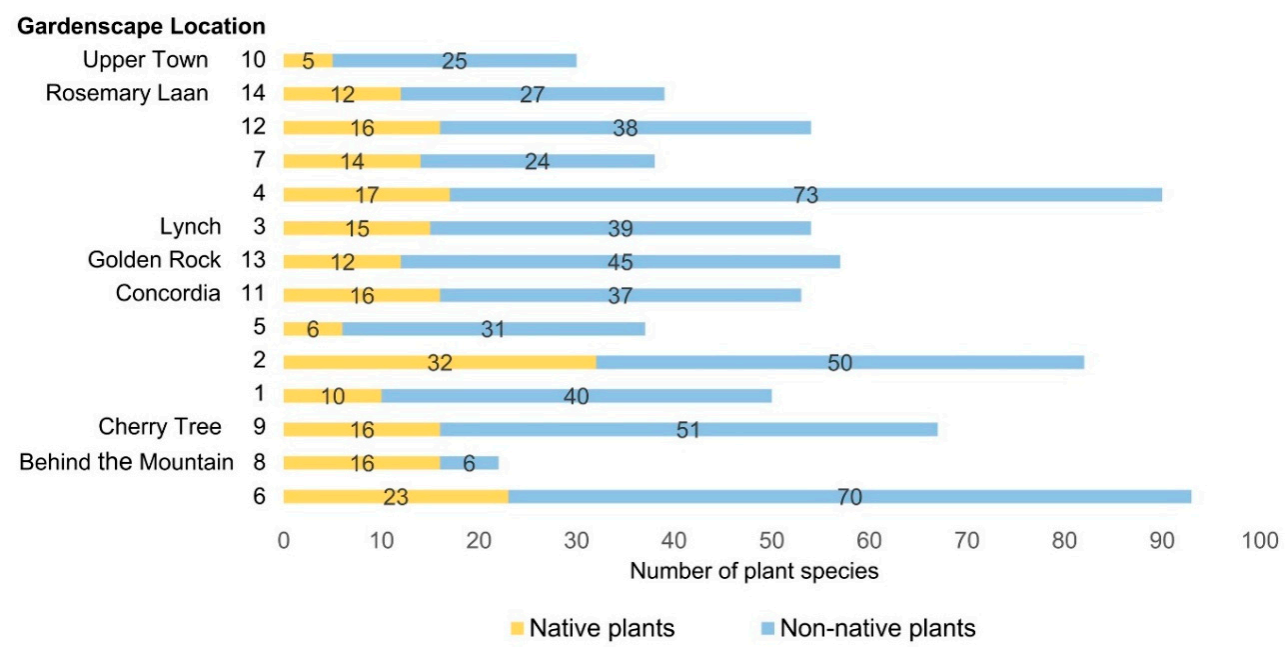

Figure 2. Species richness among the sampled gardenscapes by their origin status.

The gardens clearly show the contribution of non-native plants to their "ecological" diversity, but the survey results also highlight on average about $25 \%$ of the flora represented by native plants (Figure 2). Some of the most commonly found plants include non-native Carica papaya (papaya; 
10 gardens), Annona muricata (soursop; 10 gardens), and Anacardium occidentale (cashew; 9 gardens, and native Hymenocallis caribea (spider lily; 9 gardens). Some of the species with the highest density in gardenscapes include non-native Leucaena leucocephala with a total density of 1945/ha and Musa sp. with a density of $1560 /$ ha, and native Jatropha gossypiifolia with a density of 1226/ha. Most gardens, typical of tropical flora, showed highest species richness and plant abundances attributed to woody plants (mean $=33$ ), followed by perennial herbs (15), annual herbs (6), and biennial plants (1 or 2 present per garden) (Figure 3). Only GS 5 and 10 showed highest percentages attributed to herbaceous plants explained by the gardeners' focus on vegetable production (Figure 4).

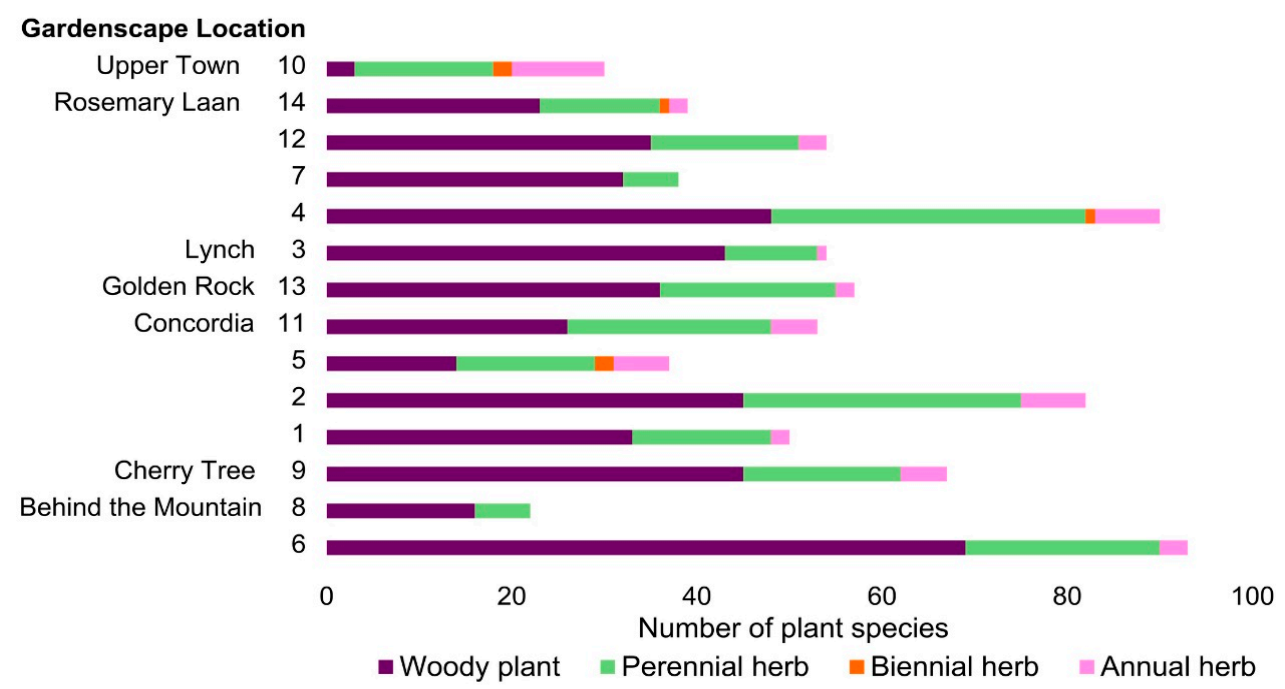

Figure 3. Species richness among the sampled gardenscapes by their growth habit.

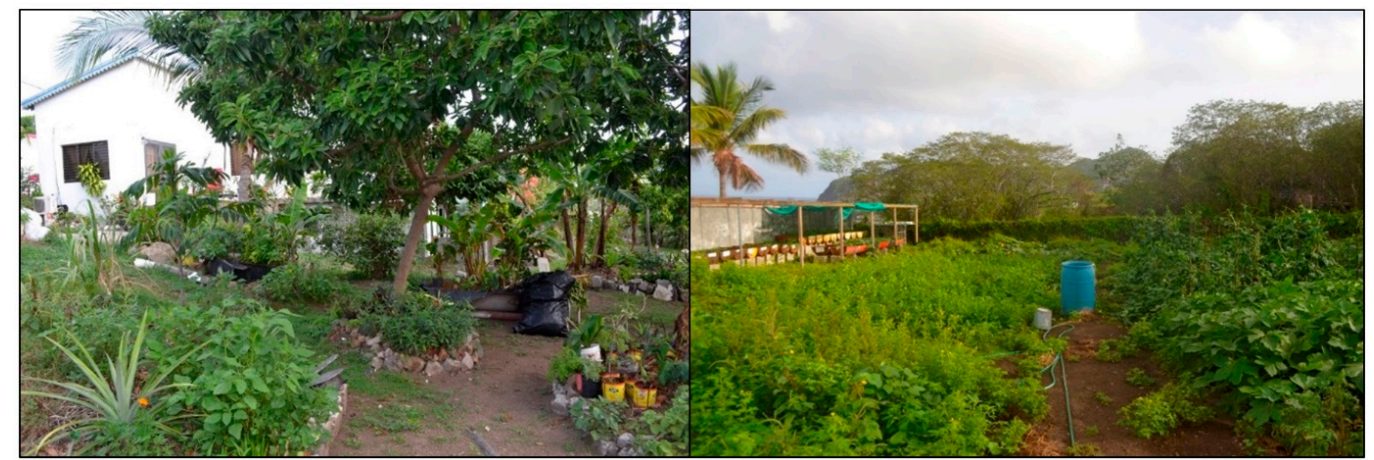

Figure 4. Variation in species richness among the sampled gardenscapes. Gardenscape 4 (left) was among the most species rich (90), with an above average species density (0.08), plant density (3193/ha) and species evenness (0.872), and showing high structural diversity. Gardenscape 10 (right) was below the average in species richness (30), species density (0.04), and plant density (794/ha), with a focus on annual vegetables and perennial herbs.

Culturally, the number of plant uses among the gardens followed species richness as nearly all species (mean $=95 \%$ ) were purposely managed in the garden (Figure 5). Gardenscapes had on average 52 plants with uses and a recorded 75 uses for their plants. Most of the plants recorded in the study were recognized for their environmental service, mostly as ornamentals, followed by food, health remedies, material uses, and symbolic services (Figure 5). GS 10, primarily a vegetable garden, showed an emphasis on food plants (Figure 4). The most diverse gardens, for example GS 4, show both species and structural complexity with ornamental trees and shrubs, planted and accidental (errant) herbs, and food production plants such as fruit trees and vegetable plants (Figure 4). 


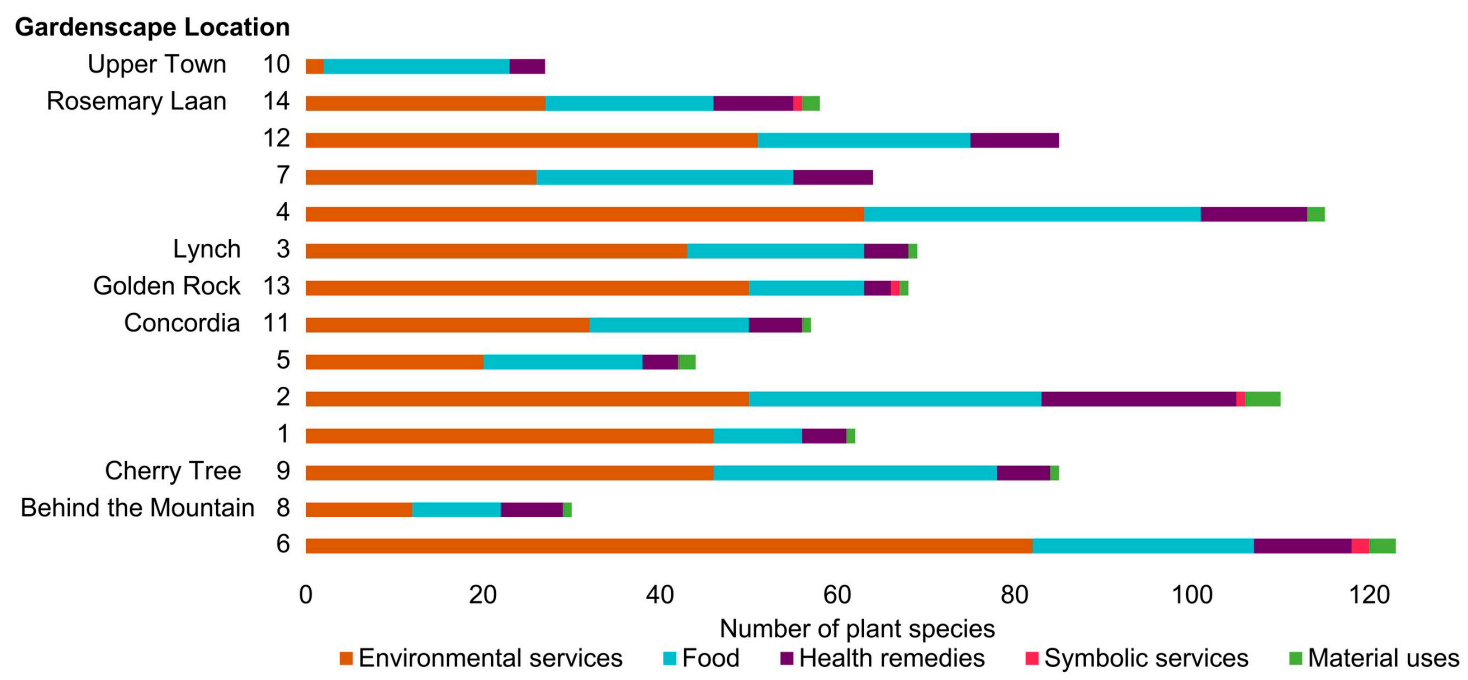

Figure 5. Ethnobotanical plant uses in gardenscapes by location.

Plot occurrences among the sample gardens explain the cumulatively high plant diversity of the surveyed gardenscapes. A jackknife analysis for the projected number of species in gardenscapes based on plot occurrences [60] provided a first order estimate of 393 species and a second-order estimate of 449. The majority of species (102) are only present in one gardenscape, and no species were recorded in all gardenscapes. GS 6, 2, and 4 have the most species overall and correspondingly also have the most unique species, with 21,15 and 14 , respectively.

\subsection{Local Perceptions on the Management and Livelihood Contributions of Gardenscapes}

Nine people said that they had grown up gardening and farming with their parents. Older gardeners who grew up on St. Eustatius said that farming was the main source of income for their parents and grandparents, which is how they learned about plants and came to love growing them. All they had was what they grew.

Five gardeners mentioned having to do a lot of work to transform their gardenscape when they first acquired it (Figure 6), while two were gardening on land that has been in their family for decades. The woman who maintains GS 1 said: "I had to remove lots of stones from my yard and planted the garden piece by piece, getting many blisters on the way". The woman from GS 15 said that there was not much in her yard when she arrived a few years ago besides a few trees, and the soil was bad with lots of sand and stones, but with fertilizer, water and shade she has been able to grow a lot. The woman who maintains GS 6, which is located behind the mountain, said that there were lots of invasive weeds on her land before she moved there such as kasha (Vachellia sp.), corallita (Antigonon leptopus), and $\tan \tan$ (Leucaena leucophala) that needed to be removed, as well as genip (Melicoccus bijugatus) and calabash (Crescentia cujete) trees that she kept. The man from GS 10 rents his land from a lady he did carpentry work for. He had to remove lots of corallita at first, plowing it up, taking out roots with a rake, and throwing it across the road into an empty lot.

All surveyed gardenscapes were maintained by the gardeners who we interviewed, but they mentioned getting help from other people, such as hired gardeners, relatives, friends, or a partner or spouse. Eight gardeners said they spend time in their gardens every day, either to maintain it or for pleasure, often in the morning when it is cooler. "Every morning I take off yellow leaves and dead flowers and give them a little sip" said the woman from GS 1. The gardener at GS 7 said that he goes to his garden every day, either in the morning or afternoon, whenever he is not busy or the trees need water, and finds that gardening does not usually take him too much time.

Plants are both cultivated by the gardener and obtained from outside sources. Seven participants mentioned plant material being brought to St. Eustatius from other islands or regions, including 
St. Maarten, St. Lucia, Colombia, Jamaica, Dominica, Florida, Suriname, US Virgin Islands, St. Kitts, Nevis, and Puerto Rico. Two participants emphasized their dedication to growing "local" fruit, such as mango, guava and soursop (all introduced), because they are easier to grow and more drought resistant. Six people said they grew their own plants from cuttings and seeds. Two gardeners said that you can buy seeds at the hardware store on St. Eustatius for vegetables such as celery and pak choy, but not in the large quantities that many of these gardeners want. The gardener from GS 10 said that he saved his own seeds, three people said they got them from friends or family, and two people mentioned getting them when they are in other countries. Three of the gardeners also gave away or sold seedlings from their own gardens.

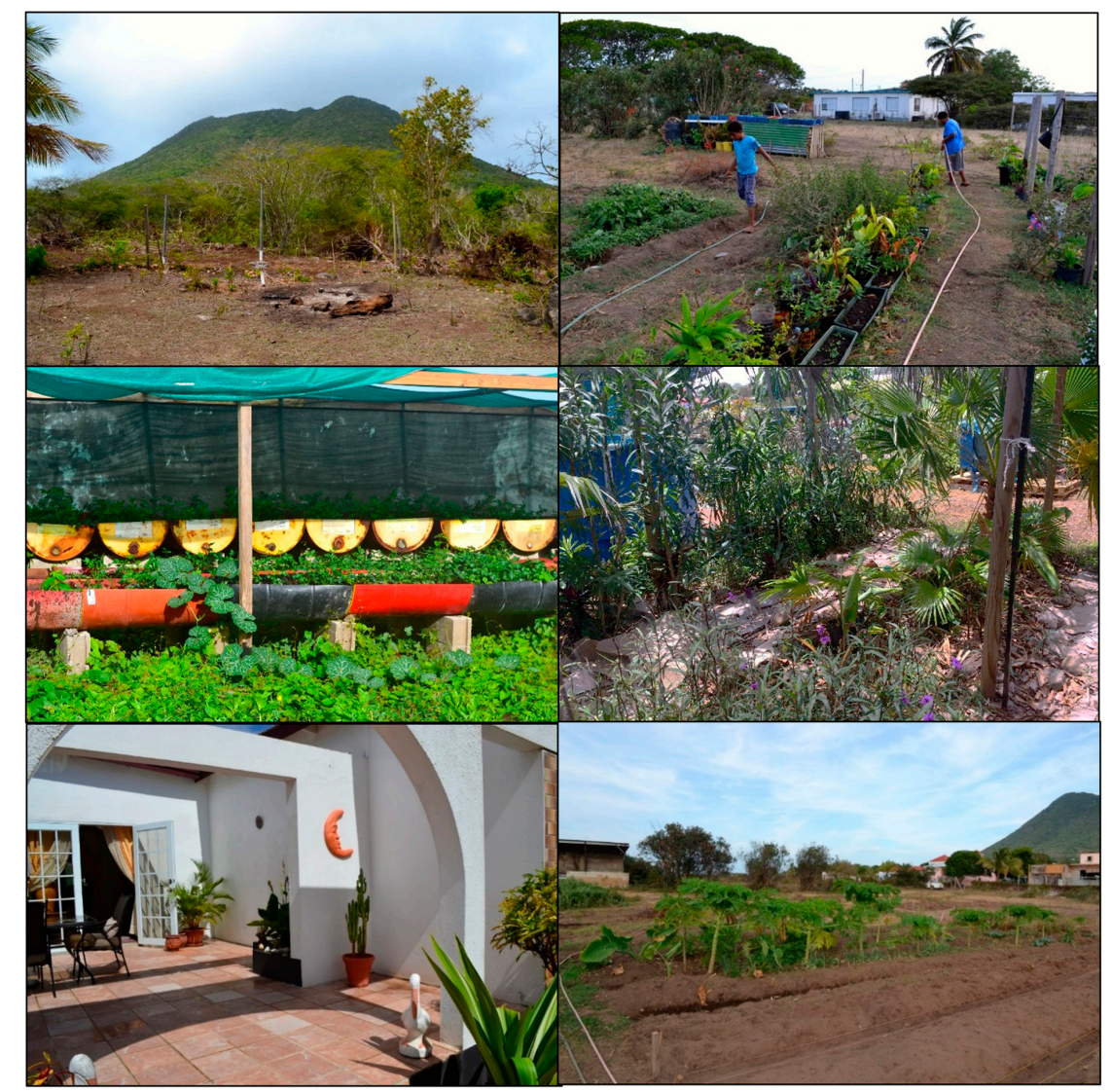

Figure 6. Field observations of gardenscapes, focusing on the transformation of the land (top) through burning and planting seedlings, ways of enriching diversity (middle) through the use of raised beds and shade, and the income contributions of gardenscape (bottom) from tourists and vegetable sales.

Interview respondents provided different perceptions on how they promote plant diversity in their gardens. Three people said that they never think about the seasons and that it is possible to grow some plants year round, though certain types of vegetables have to rotate in and out. Three people also said that they avoid consuming things that are bad for health, so prefer to grow their own food organically. A male gardener at GS 10 prefers vegetables as cash crops because they have a quicker turnaround, the women at GS 4 and GS 5 prefers fruit trees because of the healthy fruit they provide, and the male gardener at GS 7 prefers fruit trees over ornamentals because he likes getting a "reward" from his plants. The woman at GS 15 said that she started most of her fruit trees from seed, and in the five years that she has lived on St. Eustatius most of them have gotten to four or five feet tall and started to produce fruit.

Maintaining established plants can often be the biggest challenge on St. Eustatius, but people are able to successfully garden by getting water from multiple sources like catching rainwater, and 
enhancing the soil with compost, fertilizer, or manure. Gardeners also described enhancing their space by adding infrastructure to their garden such as raised beds, growing plants in pots made from household items like tin cans and water containers, and creating better growing environments for plants with shadecloth (Figure 6). Gardenscapes and the plants they contain also provide support for other species such as the endangered Iguana delicatissima and provide sources of pollen for bees and hummingbirds. Palm tree leaves were mentioned as very useful by two gardeners, both for providing shade and for putting around the base of trees to keep moisture in. The gardener from GS 9 mentioned that having lots of trees in her yard makes the whole place seem much cooler, and she had a large passion fruit (Passiflora sp.) vine forming an arbor in her yard that she used as a "greenhouse" because it stays cool and moist under it.

Eight participants reported that St. Eustatius was currently in a bad drought, which affected the plants that they could grow. Two older participants suggested that the climate on St. Eustatius had gotten drier over the years and four gardeners said that they were no longer able grow certain crops year round such as pineapple, yams, potatoes, sugar cane and pumpkins because they grow very slowly and often do not get big enough to bear fruit. In contrast, the gardener at gardenscape 13 said that trees and shrubs flower more when conditions are dry. Four participants mentioned that roaming livestock are a problem in maintaining their gardenscapes. People on St. Eustatius allow their cows and goats to roam freely on the island, and the animals are always looking for food. One woman from GS 9 just had a cow break into her yard in the middle of the night, which trampled several of her plants. Pests were identified as one of the biggest problems in gardenscapes. Three people mentioned a pest on St Eustatius that took out all their coconut trees several years ago, with one person describing it as a bug that goes inside the tree and lays eggs that hatch and eat through the middle of the tree. Mealy bugs, worms, aphids, caterpillars, white flies, fire ants, weevils, and a butterfly egg pest were also mentioned as problem insects by gardeners. Two gardeners mentioned a "tea" that can be made from boiling leaves of the neem tree (Azadirachta indica), which can then be sprayed to prevent pests such as ants and mealybugs. Thrush, rats, and snails also pose a threat to plants. Though the study reports five invasive plants, these plants were not mentioned as a problem by the gardeners. Two gardeners, when asked about the very invasive corallita vine (Antigonon leptopus) said that you just have to dig out the roots little by little every year and the plant will eventually disappear.

Gardeners had much to say about how the plants contributed to their livelihoods and to St. Eustatian society (Figure 6). Two gardeners had small inns that were run out of their homes and had nice gardens as an attraction for their customers and a source of food for their restaurants. Three people mentioned selling plants. The gardener from GS 16 said he sold tree slips to people who want to backyard garden, and also sold vegetable plants like spinach and pak choy. Health remedies were sold by the man from gardenscape 8 , who made herb treatments for dengue and chikungunya, treatments for prostate problems made from dandelion (Taraxacum officinale), and tinctures from cinnamon (Pimenta racemosa) for pain. Two gardeners sold their vegetables at a local vegetable stand or market. The gardener who manages GS 4 and GS 5 makes juices and jams from mango, gooseberry and guava, and dries herbs to sell at fairs and markets on the island. She wished there were more opportunities to sell her products. The gardener from GS 6 exchanges produce like pumpkins and beans for bottles of liquor and wine.

The study participants openly expressed how gardenscapes "personally" benefited their lives. One woman from GS 1 described how much she loves all her plants, and thinks her plants look like they were sad when she goes away. Another gardener from GS 7 said how he enjoys eating and sharing the fruit from his trees with his family and friends. He thinks gardening is relaxing and good for his health. "Every day I can't wait to get to the garden, inhale oxygen, put my fingers in the dirt". "I don't like to use gloves" said the woman from GS 9, and she also said she knows the beauty of growing your own plants. Two people said that they find gardening to be very rewarding and fun. "If you want to be independent you have to plant. You're not independent if you can't feed yourself", said the man from GS 3. Four people also emphasized that gardening had taught them the value of healthy eating. 
The consensus of eight garden participants was that people garden a lot less than they used to. The gardener from GS 15 said that getting people into gardening today is difficult because "you need money, a good fence to keep out livestock, and time". However, the gardener at GS 6 says that "you can save a lot of money gardening on St. Eustatius because produce is expensive at the grocery store", and the gardener at GS 15 says "you can grow almost anything if you know how to do it". Lack of education in schools about gardening and the importance of plants is a main reason that five people mentioned influencing the decline in gardening. The woman from GS 1 made the observation that overall St. Eustatius does not have enough vegetation, and thinks that the government should plant more trees. The participant from GS 16 works at the St. Eustatius Department of Agriculture and Fisheries, and said that $85 \%$ of food on the island is imported. He recently started a community garden initiative on Department of Agriculture land, and now has four gardeners who each have their own space (e.g., GS 5) but also help each other out with garden maintenance. Anyone can get a piece of the land, he said, and they can receive more as their garden spaces improve.

\section{Discussion}

\subsection{Gardenscapes for Biodiversity Conservation}

Gardenscapes show unique contributions to plant diversity on St. Eustatius. Our survey of 14 gardenscapes maintained by active gardeners confirmed 277 plant species in about 2 ha of land. Species richness in gardens can be very high in a small cumulative area. By comparison, similar floristic inventories found 182 plant species in 25 home gardens in Cuba [45], 177 species in 19 home gardens in Brazil [64], 600 species in 244 gardens in South Africa [65], 520 plant species in 62 home gardens in Tanzania [66], and 282 species in 328 urban home or shared apartment gardens in Bangladore, India [28]. St. Eustatian gardenscapes contain about a third native plants and two thirds non-native; findings that concur with other garden research in, for example, the UK [27] and South Africa [67]. Some restoration ecologists promote only native plants, saying that non-native plants are not positive contributions to ecological diversity due to their potential to become invasive, lack of environmental services, and unsuitable adaptability to the area where they are planted [16]. The participants in our study, however, described how these plants transformed highly degraded land, added to the availability of cultural plant resources, and made positive changes in the landscape that suggest their role as "culturally enriching" to their homes and potentially "facilitating" to native flora [68]. Although our study focused on plants, the gardeners mentioned their role in providing habitat for the endangered Iguana delicatissima and sources of pollen for bees and hummingbirds, supporting potentially a diversity of fauna through gardenscape management [16].

Species densities in gardenscapes on St. Eustatius are significantly higher than those reported for natural vegetation. The sampled gardens occurred across the "urban wasteland" mapped by De Freitas et al. [48] and described by Van Andel et al. [46] (p. 65) as: "open vegetation, entirely covered by a blanket of the invasive corallita vine (Antigonon leptopus), contains a few scattered trees, like Leucaena leucocephala (also an invasive) and the cultivated fruit tree Melicoccus bijuga, whose broad crown shades out the corallita, allowing space for a few other herbs and grasses". Low woody plant density and richness reported for more "natural" tropical dry vegetation types [46] contrast with the structural heterogeneity found in most gardenscapes. The gardenscapes, while showing an emphasis on non-native ornamentals, exemplify the mixed composition of species found from different origins characteristic of secondary succession in the Caribbean [41,69] and contribute to diversity patterns on the island as their own "novel ecosystem" [70].

High measures of ecological diversity in gardenscapes also corresponded to high ethnobotanical diversity on St. Eustatius. While over half of the surveyed plant species were recognized as ornamental, the study reports multiple uses for these plants, a high number of plants with uses, and similar to studies in Cuba [45] and South Africa [67], a high number of plant uses for food and health remedies. Reyes-Garcia et al. [71] say that ornamental and medicinal plants increase a garden's diversity because 
people tend to plant a smaller number of more varied species. Our sample included gardens maintained by women and men, and similar to findings in Cuba [45], the male gardeners showed a particular interest in food crops, and two of the oldest women participants with diverse gardenscapes provided examples and descriptions for nearly all the reported medicinal plant uses. Female gardeners had more diverse gardens and talked extensively about the aesthetic values of their plants. Home garden characteristics reflect cultural gender roles and expectations [71]. Study participants also indicated being worried about plant knowledge declining among younger men and women, which is a common finding in ethnobotanical research [61,72].

Many plants have heritage, exemplified by Carney's [73] publication on how Africans, when brought to the Americas under slavery, also brought over Old World plants and plant uses. For example, the fruits from Blighia sapida and Tamarindus indica, remedies for Phyllanthus amarus and Moringa oleifera reported in our study owe their origin to Africa or through earlier exchanges between India and Africa [73]. Gardens potentially contribute toward conserving a complex cultural history in the Caribbean and cultural knowledge across highly modified landscapes. Half of the participants in the study are migrants to the region, highlighting their access to and knowledge of different plants. Gardens provide a way for people to retain and add to their cultural identity [74].

\subsection{Gardeners Create Diverse and Meaningful Gardenscapes}

WinklerPrins [75] (p. 59) states that: “(g)ardens are an important place to 'be' and a place to do 'work'" Gardens contribute meaningfulness to "a sense of place", through the transformation of the garden space, the use of derived products, and a connection to the wider gardening community [76]. The work that gardeners on St. Eustatius had to do to create their gardenscape was in most cases very labor intensive, and they are attached to their spaces that they have so significantly transformed. Zimmerer [77] talks about recognizing landscapes as basic to environmental knowledge, being the place where local knowledge is integrated with resource management and scientific knowledge.

St. Eustatian gardeners are in possession of what is termed local ecological knowledge (LEK), experiential knowledge derived from lived interactions with the local environment, which when researched can provide meaningful biocultural data for informing conservation management $[10,78]$. The gardeners are the "experts", acknowledging their "experiences and priorities" [79] (p. 463). They knew how to get extra shade from the hot sun, which plants are easier (native fruit trees) or more difficult (plants of European origin) to grow on the island, and how to effectively deal with pests. Moreover, the study suggests that local knowledge is adaptive to observed changes in environmental and socioeconomic conditions [80], which is important on St. Eustatius where gardeners report drought becoming more common. Gardenscape LEK might be especially important for the management of invasive species. Corallita (Antigonon leptopus) is the most invasive plant on St. Eustatius, covering as much as $30 \%$ of the island [80]. Though the plant was present in eight gardens, the gardeners did not describe the plant as a major nuisance and had techniques for its management. Tan tan (Leucophala leucaena) and neem (Azadirachta indica), two other common invasive species on the island [69], were also present and valued in two gardenscapes. LEK about invasive species control helps efforts to manage and restore gardenscapes and can also have wider implications for plant conservation on the island. Our study supports garden research that substantiates views from multiple "experts" as they cumulatively provide different reasons for producing diverse gardens and contribute to their effective management $[54,79]$.

The results of this study make it apparent that the plants a gardener chooses to grow and the techniques that they use to manage their plants directly impact biodiversity levels in gardenscapes. The most diverse gardens in our study were also the most "messy" [81], with more weedy plants and a less manicured appearance. Moreover, adding infrastructure to a gardenscape in the form of raised beds, planted pots or delineated beds adds to overall garden diversity, providing more densely packed and higher potential production areas. Multifunctional gardenscapes support heterogeneity in structure and purpose, and accordingly offer a "sustainable intensification" [82] 
that can effectively integrate agrobiodiversity through their management as "conservation units for native plants and reservoirs of exotic plants from different origins" [83] (p. 1). We report unique species occurrences, distinctive ecological attributes, and different perspectives on how people place and value gardenscapes in their lives. The study highlights the positioning of gardenscapes as a "social-ecological systems framework", emphasizes their ecological, social, and economic contributions to sustainable development, and substantiates the potential contributions of multiple stakeholders and multiple objectives that jointly address conservation and human livelihoods [31]. Preserving biodiversity is as much about the people as it is about the places, and needs to more deeply consider local decision-making about resource use and management [84].

\section{Conclusions}

The high plant diversity and complex ecological structures represented by the sampled gardenscapes, and the ways that people introduce and manage plants, support their recognition as potential sites of restoration [30], and adds support to an extensive global literature that highlights the potential contributions of gardens as sustainable landscape management. Gardenscapes provide an important way to strengthen biocultural approaches and, accordingly, community involvement in conservation on St. Eustatius. Although St. Eustatius National Parks (STENAPA) manages protected areas and a botanical garden, which promote flora and fauna on the island, they need not be and should not be the sole beacon of biodiversity conservation on the island.

Gardenscapes on St. Eustatius have the potential to enrich degraded land, but only if local people are recognized for their individual contributions and specifically targeted to become more involved in garden management. The mixed methods employed in this study highlight the power of sharing knowledge through collaborative research. We emphasize the important work of starting dialogues about gardening on the island, and recording data that provide an opportunity for shared learning about gardenscapes. Adaptive co-management that aims to incorporate ecological knowledge and management of ecosystems on a variety of scales and amongst diverse actors [85] can guide the management of gardenscapes as a collaborative process between the gardeners and conservation agencies. The community garden managed by the Agriculture Department and STENAPA's botanical garden on the island offer potential "boundary organizations" that can facilitate communication in this Caribbean setting and effectively support "the knowing-doing gap" [86] (p. 87). Sustainable landscape management for plant diversity needs to more holistically recognize how and why plants are being conserved and better utilize the important biocultural knowledge and understanding that local people hold about ways to improve their local landscapes through garden management.

Supplementary Materials: The following are available online at www.mdpi.com/2071-1050/9/8/1310/s1, Table S1. Floristic and ethnobotanical inventory of plants confirmed in the surveyed gardenscapes on St. Eustatius. Nomenclature and plant origins as native or non-native follow Plants of the Eastern Caribbean, an online database maintained by the University of the West Indies in Barbados, Acevedo-Rodriguiz and Strong's (2012) "Catalogue of seed plants of the West Indies", Rojer's (1997) floristic inventory of St. Eustatius, and a report by van der Burg (2012) on naturalized and invasive plants in the Dutch Caribbean. Common names (in bold) were provided by the study participants and local field assistants, or shown on display at the St. Eustatius National Parks (STENAPA) botanical garden. Plant types include trees $(\mathrm{t})$, shrubs $(\mathrm{s})$ or herbs $(\mathrm{h})$, and origins are reported as native or non-native introduced (int), naturalized (nat) or invasive (inv). Ethnobotanical use categories include ecosystem services (ES), food (F), health remedies (HR), material uses (M), and symbolic services (SS). Voucher specimens (BB) were deposited at Miami University's Turrell Herbarium (MU).

Acknowledgments: This research was supported by grants from the Willard Sherman Turrell Herbarium (\#229), the Department of Geography, and the Graduate School at Miami University. We especially thank our field research assistants, Hannah Madden and Celford Gibbs, the gardenscape participants for generously welcoming us into their gardens, and Michael Vincent, Director of the Turrell Herbarium, for his Caribbean flora expertise, assistance in processing the plant vouchers, and review of the plant list. The Caribbean Netherlands Science Institute (CNSI) and St. Eustatius National Parks Foundation (STENAPA) provided logistical assistance. We thank Mary Jane Berman and David Prytherch for their valuable comments as committee members for the MA thesis upon which this paper is based, and two anonymous reviewers for their comments on an earlier draft of this research paper. 
Author Contributions: B.N.B. and K.E.M. conceived and designed the thesis research; B.N.B. conducted the field study with local participants and completed all data analyses; B.N.B. and K.E.M. wrote the paper.

Conflicts of Interest: The authors declare no conflicts of interest.

\section{References}

1. Zimmerer, K.S.; Young, K.R. Introduction: The geographical nature of landscape change. In Nature's Geography: New Lessons for Conservation in Developing Countries; Zimmerer, K.S., Young, K.R., Eds.; University of Wisconsin Press: Madison, WI, USA, 1998; pp. 3-34.

2. Hamilton, A.; Hamilton, P. Plant Conservation: An Ecosystem Approach; Earthscan: London, UK, 2006.

3. Fabricius, C.; Folke, C.; Cundill, G.; Schultz, L. Powerless spectators, coping actors, and adaptive co-managers: A synthesis of communities in ecosystem management. Ecol. Soc. 2007, 12, 29. [CrossRef]

4. Fagerholm, N.; Kayhko, N.; Ndumbaro, F.; Khamis, M. Community stakeholders' knowledge in landscape assessments-Mapping indicators for landscape services. Ecol. Indic. 2012, 18, 421-433. [CrossRef]

5. Alcorn, J.B. The scope and aims of ethnobotany in a developing world. In Ethnobotany; Schultes, R.E., von Reis, S., Eds.; Timber Press: Portland, OR, USA, 1995; pp. 23-39.

6. Anderson, E. Plants, Life, and Man; University of California Press: Berkeley, CA, USA, 1967.

7. Wilson, E.O. Biophilia; Harvard University Press: Cambridge, MA, USA, 1984.

8. Head, L.; Atchison, J. Cultural ecology: Emerging human-plant geographies. Prog. Hum. Geogr. 2009, 33, 236-245. [CrossRef]

9. Nabhan, G.P. (Ed.) Ethnobiology for the Future: Linking Cultural and Ecological Diversity; University of Arizona Press: Tucson, AZ, USA, 2016.

10. Gavin, M.C.; McCarter, J.; Mead, A.; Berkes, F.; Stepp, J.R.; Peterson, D.; Tang, R. Defining biocultural approaches to conservation. Trends Ecol. Evol. 2015, 30, 140-145. [CrossRef] [PubMed]

11. Mills, S. Restoring and renewing whole ways of life. In Healing Natures, Repairing Relationships; France, R.L., Ed.; Green Frigate Books: Sheffield, VT, USA, 2008; pp. 117-125.

12. Allison, S.K. What do we mean when we talk about ecological restoration? Ecol. Restor. 2004, 22, $281-286$. [CrossRef]

13. Kimber, C.T. Martinique Revisited: The Changing Plant Geographies of a West Indian Island; Texas A\&M University Press: College Station, TX, USA, 1988.

14. France, R.L. Introduction: Engaging nature and establishing relationships. In Healing Natures, Repairing Relationships; France, R.L., Ed.; Green Frigate Books: Sheffield, VT, USA, 2008; pp. 7-20.

15. Higgs, E. Nature by Design; The MIT Press: Cambridge, MA, USA, 2003.

16. Tallamy, D. Bringing Nature Home; Timber Press: Portland, OR, USA, 2009.

17. Marris, E. The Rambunctious Garden: Saving Nature in a Post-Wild World; Bloomsbury: New York, NY, USA, 2013.

18. Cunningham, A. Applied Ethnobotany: People, Wild Plant Use and Conservation; Earthscan: London, UK, 2001.

19. Kumar, B.M.; Nair, P.K.R. (Eds.) Tropical Homegardens: A Time-Tested Example of Sustainable Agroforestry; Springer: Dodrecht, The Netherlands, 2006.

20. Beumer, C.; Martens, P. Biodiversity in my (back)yard: Towards a framework for citizen engagement in exploring biodiversity and ecosystem services in residential gardens. Sustain. Sci. 2015, 10, 87-100. [CrossRef]

21. Pollan, M. Second Nature: A Gardener's Education; The Atlantic Monthly Press: New York, NY, USA, 1991.

22. Higgs, E. Focal Restoration. In Ecological Restoration: A Global Challenge; Comin, F., Ed.; Cambridge University Press: Cambridge, UK, 2010; pp. 91-99.

23. Ahren, J. Urban landscape sustainability and resilience: The promise and challenges of integrating ecology with urban planning and design. Landsc. Ecol. 2013, 28, 1203-1212. [CrossRef]

24. Greipsson, S. Restoration Ecology; Jones \& Bartlett Learning: Sudbury, MA, USA, 2011.

25. Estrada-Carmona, N.; Hart, A.K.; DeClerck, F.A.J.; Harvey, C.A.; Milder, J.C. Integrated landscape management for agriculture, rural livelihoods, and ecosystem conservation: An assessment of experience from Latin America and the Caribbean. Landsc. Urban Plan 2014, 129, 1-11. [CrossRef]

26. Rapoport, E.H. The process of plant colonization in small settlements and large cities. In Humans as Components of Ecosystems: The Ecology of Subtle Human Effects and Populated Areas; McDonnell, M.J., Pickett, S.T.A., Eds.; Springer: New York, NY, USA, 1993; pp. 190-207. 
27. Loram, A.; Thompson, K.; Warren, P.H.; Gaston, K.J. Urban domestic gardens (XII): The richness and composition of the flora in five UK cities. J. Veg. Sci. 2008, 19, 321-330. [CrossRef]

28. Jaganmohan, M.; Vailshery, L.S.; Gobal, D.; Nagendra, H. Plant diversity and distribution in urban domestic gardens and apartments in Bangalore, India. Urban Ecosyst. 2012, 15, 911-925. [CrossRef]

29. Gbedomon, R.C.; Fandohan, A.B.; Salako, V.K.; Idohou, A.F.R.; Kakai, R.G.; Assobadjo, A.E. Factors affecting home gardens ownership, diversity and structure: A case study from Benin. J. Ethnobiol. Ethnomed. 2015, 11, 56. [CrossRef] [PubMed]

30. Allison, S.K. Ecological Restoration and Environmental Change: Renewing Damaged Ecosystems; Routledge: Abingdon, UK, 2012.

31. Sayer, J.; Sunderland, T.; Ghazoul, J.; Pfund, J.-L.; Sheil, D.; Meijaard, E.; Venter, M.; Boedhihartono, A.K.; Day, M.; Garcia, C.; et al. Ten principles for a landscape approach to reconciling agriculture, conservation, and other competing land uses. Proc. Natl. Acad. Sci. USA 2013, 110, 8349-8356. [CrossRef] [PubMed]

32. Rojer, A. Biological Inventory of Sint Eustatius; Carmabi Foundation: Curaçao, Netherland Antilles, 1997. Available online: http:/ / www.statiapark.org/downloads/downloads/RojerKNAP96-33BioInv-statia\% 5Beng\%5D.PDF (accessed on 27 June 2017).

33. Verheijden, T. Ethnobotanical Knowledge Loss on the Caribbean Island of St. Eustatius. Internship Report for Naturalis Biodiversity Center, Leiden, The Netherlands, 2016. Available online: http: / / www.dcbd.nl/sites / www.dcbd.nl/ files / documents /Verheijden\%202016.\%20Etnobotanical\% 20knowledge \%20loss\%20on\%20the\%20Caribbean\%20island\%20of\%20St.Eustatius.pdf (accessed on 27 June 2017).

34. Critical Ecosystem Partnership Fund. Caribbean Islands Biodiversity Hotspot: Ecosystem Profile Summary; Conservation International: Arlington, VA, USA, 2010. Available online: http://www.cepf.net/ SiteCollectionDocuments / caribbean/Caribbean_EP_Summary.pdf (accessed on 27 June 2017).

35. Maunder, M.; Leiva, A.; Santiago-Valentin, E.; Stevenson, D.W.; Acevedo-Rodriguez, P.; Meerow, A.W.; Meija, M.; Clubbe, C.; Fransisco-Ortega, J. Plant conservation in the Caribbean island biodiversity hotspot. Bot. Rev. 2008, 74, 197-207. [CrossRef]

36. Deloughrey, E. Island ecologies and Caribbean literatures. Tijdschr. Econ. Soc. Geogr. 2004, 95, $298-310$. [CrossRef]

37. Fitzpatrick, S.M.; Keegan, W.F. Human impacts and adaptations in the Caribbean Islands: An historical ecology approach. Earth Environ. Sci. Trans. R. Soc. Edinb. 2007, 98, 29-45. [CrossRef]

38. McNeill, J.R. Mosquito Empires: Ecology and War in the Greater Caribbean, 1620-1914; Cambridge University Press: Cambridge, UK, 2010.

39. Morgan, M.; Zimmerman, T.W. Agroforestry in the Caribbean, traditional systems, both sustainable and biodiverse. In Sustainable Horticultural Systems: Issues, Technology, and Innovation; Nandwani, D., Ed.; Springer: New York, NY, USA, 2014; pp. 129-142.

40. Lugo, A.E.; Helmer, E.H.; Valentin, E.S. Caribbean landscapes and their biodiversity. Interciencia 2012, 37, 705-710.

41. Lugo, A.E. Can we manage tropical landscapes?-An answer from the Caribbean perspective. Landsc. Ecol. 2002, 17, 601-615. [CrossRef]

42. Martin, T. Caribbean History: From Pre-Colonial Origins to the Present; Pearson: Upper Saddle River, NJ, USA, 2012.

43. Kimber, C.T. Spatial patterning in the dooryard gardens of Puerto Rico. Geogr. Rev. 1973, 63, 6-29. [CrossRef]

44. Brierly, J.S. Kitchen gardens in the Caribbean, past and present: Their role in small farm development. Caribb. Geographer. 1991, 3, 15-28.

45. Buchmann, C. Cuban home gardens and their role in socio-ecological resilience. Hum. Ecol. 2009, 37, 705-721. [CrossRef]

46. Van Andel, T.; van de Hoorn, B.; Stech, M.; Arostegui, S.B.; Miller, J.A. A quantitative assessment of the vegetation types on the island of St. Eustatius, Dutch Caribbean. Glob. Ecol. Conserv. 2016, 7, 59-69. [CrossRef]

47. World Wildlife Fund. Islands of the Lesser Antilles in the Caribbean. Available online: https://www. worldwildlife.org/ecoregions/nt0220 (accessed on 27 June 2017).

48. De Freitas, J.A.; Rojer, A.C.; Nijhof, B.S.J.; Debrot, A.O. A Landscape Ecological Vegetation Map of Sint Eustatius (Lesser Antilles); IMARES; CARMABI and Royal Netherlands Academy of Arts and Sciences: Amsterdam, The Netherlands, 2012. 
49. St. Eustatius Center for Archaeological Research. The Early Years. Available online: http://secar.org/en/steustatius / brief-history / the-early-years-historic-period-ad-1492-20th-century (accessed on 27 June 2017).

50. Aceto, M. Statian Creole English: An English-derived language emerges in the Dutch Antilles. World Engl. 2006, 25, 411-435. [CrossRef]

51. Palmer, D.T. St. Eustatius, Netherland Antilles. In Encyclopedia of Historical Archaeology; Orser, C.E., Jr., Ed.; Routledge: London, UK, 2014; p. 527.

52. Stelten, R. Archaeological excavations at Schotsenhoek Plantation, St. Eustatius, Caribbean Netherlands. Research report. St. Eustatius Center for Archaeological Research: St. Eustatius, Dutch Caribbean, 2013. Available online: http:/ / secar.org/uploads/user/9ad7a1_3680bff2b18040baacd7109f6ae959f2.pdf (accessed on 27 June 2017).

53. Statistics Netherlands. Population of St. Eustatius Revised Downwards. 19 December 2016. Available online: https:/ / www.cbs.nl/en-gb/news/2016/51/population-of-st-eustatius-revised-downwards (accessed on 17 June 2017).

54. Vogl, C.R.; Vogl-Lukasser, B.N.; Puri, R.K. Tools and methods for data collection in ethnobotanical studies of homegardens. Field Methods 2004, 16, 285-306. [CrossRef]

55. Oberhauser, A.M. The home as "field": Households and homework in rural Appalachia. In Thresholds in Feminist Geography: Difference, Methodology, Representation; Jones, J.P., III, Nast, H.J., Roberts, S.M., Eds.; Rowman \& Littlefield Publishers: Lanham, MD, USA, 1997; pp. 165-182.

56. Sewell, S.; Harris, N. Exploring local women's care for the local environment: A community-based feminist participatory research approach. Community Dev. J. 2016, 51, 195-211. [CrossRef]

57. Berkowitz, B. Home Gardenscapes for the Promotion of Ecological and Cultural Plant Diversity. Master's Thesis, Miami University, Oxford, OH, USA, 2017.

58. Acevedo-Rodríguez, P.; Strong, M.T. Catalogue of seed plants of the West Indies. Smithson. Contrib. Bot. 2012, 98, 1-1192. [CrossRef]

59. Van der Burg, W.J.; de Freitas, J.; Debrot, A.O.; Lotz, L.A.P. Naturalized and Invasive Alien Plant Species in the Caribbean Netherlands: Status, Distribution, Threats, Priorities, and Recommendations; Research Report; Plant Research International: Wageningen, The Netherlands, 2012. Available online: http:/ / edepot.wur.nl/198282 (accessed on 27 June 2017).

60. McCune, B.; Grace, J.B. Analysis of Ecological Communities; MJM Software Design: Gleneden Beach, OR, USA, 2002.

61. Martin, G.J. Ethnobotany: A Methods Manual; Earthscan: London, UK, 2004.

62. Gallaher, C.M.; WinklerPrins, A.; Njenga, M.; Karanja, N.K. Creating Space: Sack Gardening as a Livelihood Strategy in the Kibera Slums of Nairobi, Kenya. J. Agric. Food Syst. Community Dev. 2015, 5, 1-19. [CrossRef]

63. St. Eustatius Animal Welfare Foundation. St. Eustatius Rain History 1981-Today. Available online: http:/ / www.seawf.com/rainhist.php (accessed on 27 June 2017).

64. Carvalho, T.K.N.; de Oliveira Abreu, D.B.; de Lucena, C.M.; Pedrosa, K.M.; Neto, C.F.A.V.; Alves, C.A.B.; Felix, L.P.; Florentino, A.T.N.; Alves, R.R.N.; de Andrade, L.A.; et al. Structure and floristics of home gardens in an altitudinal marsh in northeastern Brazil. Ethnobot. Res. Appl. 2013, 11, 29-48.

65. Davoren, E.; Siebert, S.; Cilliers, S.; du Toit, M.J. Influence of socioeconomic status on design of Batswana home gardens and associated plant diversity patterns in Northern South Africa. Landsc. Ecol. Eng. 2016, 12, 129-139. [CrossRef]

66. Hemp, A. The banana forests of Kilimanjaro: Biodiversity and conservation of the Chagga homelands. Biodivers. Conserv. 2006, 15, 1193-1217. [CrossRef]

67. Gabolwelwe, M.; Maroyi, A.; Potgieter, M. Comparative analysis of plant use in peri-urban domestic gardens of the Limpopo Province, South Africa. J. Ethnobiol. Ethnomed. 2014, 10. [CrossRef]

68. Pfeiffer, J.; Voeks, R.A. Biological invasions and biocultural diversity: Linking ecological and cultural systems. Environ. Conserv. 2008, 35, 281-291. [CrossRef]

69. Weaver, P.L.; Schwagerl, J.J. Secondary forest succession and tree planting at the Laguna Cartagena and Cabo Rojo wildlife refuges in southwestern Puerto Rico. Ambio 2008, 37, 598-603. [CrossRef] [PubMed]

70. Franklin, J.; Ripplinger, J.; Freid, E.H.; Marcano-Vega, H.; Steadman, D.W. Regional variation in Caribbean dry forest tree species. Plant Ecol. 2015, 216, 873-886. [CrossRef] 
71. Reyes-Garcia, V.; Aceituno-Mata, L.; Calvet-Mir, L.; Garnatje, T.; Gomez-Baggethun, E.; Lastra, J.J.; Ontillera, R.; Parada, M.; Rigat, M.; Valles, J.; et al. Resilience of traditional knowledge systems: The case of agricultural knowledge in home gardens in the Iberian Peninsula. Glob. Environ. Chang. 2014, 24, 223-231. [CrossRef]

72. Voeks, R.A.; Leony, A. Forgetting the forest: Assessing medicinal plant erosion in eastern Brazil. Econ. Bot. 2004, 58, 294-306. [CrossRef]

73. Carney, J.A. African traditional plant knowledge in the circum-Caribbean region. J. Ethnobiol. 2003, 23, 167-185.

74. Kimber, C.T. Gardens and dwelling: People in vernacular gardens. Geogr. Rev. 2004, 94, 263-283. [CrossRef]

75. WinklerPrins, A.M.G.A. House-lot gardens in Santarém, Pará, Brazil: Linking rural with urban. Urban Ecosyst. 2003, 6, 43-65. [CrossRef]

76. Dunlap, R.; Harmon, J.; Kyle, G. Growing in place: The interplay of urban agriculture and place sentiment. Leisure 2013, 37, 397-414. [CrossRef]

77. Zimmerer, K.S. Report on geography and the new ethnoecology. Geogr. Rev. 2001, 91, 725-734. [CrossRef]

78. Turvey, S.; Fernandez-Secades, C.; Nunez-Mino, J.M.; Hart, T.; Martinez, P.; Brocca, J.L.; Young, R.P. Is local ecological knowledge a useful conservation tool for small mammals in a Caribbean multicultural landscape? Biol. Conserv. 2014, 169, 189-197. [CrossRef]

79. Davis, A.; Wagner, J.R. Who knows? On the importance of identifying "experts" when researching local ecological knowledge. Hum. Ecol. 2003, 31, 463-489. [CrossRef]

80. Berkowitz, B. The state of Antigonon Leptopus (Corallita) on St. Eustatius in 2014; Internship Report; St. Eustatius National Parks Foundation: St. Eustatius, The Netherlands, 2014.

81. Nassauer, J.I. Messy ecosystems, orderly frames. Landsc. J. 1995, 14, 161-170. [CrossRef]

82. Fischer, J.; Meacham, M.; Queiroz, C. A plea for multifunctional lanadcapes. Front. Ecol. Environ. 2017, 15, 59. [CrossRef]

83. Peroni, N.; Hanazaki, N.; Begossi, A.; Zuchwschi, E.; Lacerda, V.D.; Mlranda, T.M. Homegardens in a micro-regional scale: Contributions to agrobiodiversity conservation in an urban-rural context. Ethnobiol. Conserv. 2016, 5. [CrossRef]

84. Mascia, M.B.; Brosius, J.P.; Dobson, T.A.; Forbes, B.C.; Horowitz, L.; McKean, M.A.; Turner, N.J. Conservation and the social sciences. Conserv. Biol. 2003, 17, 649-650. [CrossRef]

85. Olsson, P.; Folke, C.; Berkes, F. Adaptive Comanagement for Building Resilience in Social-Economic Systems. Environ. Manag. 2004, 34, 75-90. [CrossRef] [PubMed]

86. Jacobs, K.R.; Nicholson, L.; Murry, B.A.; Maldonado-Román, M.; Gould, W.A. Boundary organizations as an approach to overcoming science-delivery barriers in landscape conservation: A Caribbean case study. Caribb. Nat. 2016, 1, 87-107.

(C) 2017 by the authors. Licensee MDPI, Basel, Switzerland. This article is an open access article distributed under the terms and conditions of the Creative Commons Attribution (CC BY) license (http://creativecommons.org/licenses/by/4.0/). 